\title{
THE ECONOMIC WELL-BEING OF BLACK AMERICANS: THE OVERARCHING INFLUENCE OF U.S. IMMIGRATION POLICIES
}

\author{
Vernon M. Briggs, Jr.
}

Of the myriad public policies that have impinged on the economic well being of black Americans over the years, none has had more overarching and continuous effects than those pertaining to immigration. Immigration policies and trends have set the stage that has allowed other outcomes to happen. From the beginning, when blacks were introduced into the British colonies that would later become the United States, to contemporary times, when the nation finds itself in the throes of the largest and longest period of mass immigration in its history, immigration policy has significantly influenced the geographical, occupational, and industrial employment patterns of black Americans. ${ }^{1}$

Given the harrowing experiences of black Americans as the only racial or ethnic group to have ever been collectively subjected to both enforced slavery and de jure segregation, no form of public policy should be allowed to do harm to their quest to overcome these imposed handicaps. Unfortunately, U.S. immigration policy has not held to that standard. The burden of this neglect continues to this day.

\section{THE NATURE OF IMMIGRATION POLICY: A BRIEF DIGRESSION}

Before proceeding, it is necessary to mention briefly the special nature of immigration policy. Unlike most types of public policies, immigration policy falls exclusively within the province of the federal government. It is at the local and state levels, however, that immigration exerts its economic, political, and social influences. The governmental bodies at these levels have no say at all as to what the prevailing federal policies should be. They and their residents can only respond to the consequences.

Given the prominent role that immigration has played in the history of 
the nation, it is surprising that the subject is not mentioned anywhere in the U.S. Constitution. But as its significance was gradually recognized, the federal government - in the latter part of the nineteenth centurysought exclusive responsibility to regulate all aspects of immigration. Through a series of U.S. Supreme Court decisions, such authority was finally formalized. ${ }^{2}$ In essence, these decisions state that the power to regulate immigration-while not specified-is a plenary power of the national government that is inherent in the metaphysical concept of "national sovereignty." Being a nation implies a claim of authority to govern a prescribed land area in order to protect and to serve those people who live therein. The U.S. government, therefore, has the duty to set annual admission levels; to establish admission categories; to specify entry requirements; to order entry priorities; and to enforce the restrictions it imposes. No citizen of a foreign country has a right to reside, visit, enter, work, or seek refuge in the United States simply because of a desire to do so. They may only legally do any of these activities with the expressed permission of policies enacted by the federal government. Accompanying such exclusive regulatory power is an implied duty to design an immigration policy that conforms to the best interests of the citizens of the United States.

It is true, of course, that ever since the federal government has sought to screen would-be immigrants and to limit immigration, a significant number of persons have simply ignored the policy restrictions and have illegally entered or overstayed their visas. Thus, immigration policy includes the necessary commitment to enforce the policies that are put in place.

\section{THE PRE-NATION LEGACY OF IMMIGRATION}

The roots of the influence of immigration on the black experience stem from the nation's lengthy history as a British colony. Shortly after the founding of the first permanent British settlement at Jamestown, Virginia in 1607, blacks became part of the settlement movement. The first blacks were brought to the colony in 1619 aboard a Dutch slave ship. As there was no tradition of slavery in British colonies at the time, blacks were initially treated the same as were most white settlers at the time. They and others who followed became indentured servants. They were expected to work to pay off the cost of their transport and, in the process, gain their freedom at some future time. Between 1640 and 1660, however, this system came to and end. ${ }^{3}$ Blacks were no longer treated as indentured servants; their servi- 
tude would be life long. Thus, racism cannot explain the actual origins of slavery in the English colonies, but it soon became the rationale for its continuance.

For present purposes, the formalization of the use of slave labor and the subsequent importation of tens of thousands of black slaves during the remainder of British rule meant that blacks would be the paramount exception to the labor acquisition process during colonial times. Blacks would enter the colonies as "involuntary immigrants" for over two hundred years.

Although slaves could be found in all thirteen British colonies, the slave system of work was overwhelmingly concentrated in the South. The lasting influence of this process has been that the majority of the nation's black population has to this day always resided in the South. Employment patterns of blacks, therefore, have been disproportionably linked to the industries and occupations associated with the development of the southern economy-especially to its rural sector.

Initially, slavery grew slowly in the South. But in the 1690s the rise of the southern plantation system caused the demand for slaves to increase dramatically. In response, the flow of imported slaves became enormous. By 1710, this influx of more "involuntary immigrants" had reduced the supply of white indentured servants to the South to negligible numbers. ${ }^{4}$ The legacy of this regional labor supply policy was that the white indentured servants from Europe and their lineal successors- the European immigrants - became the backbone of the work force of the North and Midwest but not of the South. By the time the colonies won their independence and the United States formally became a nation in 1788 (with the ratification of the U.S. Constitution), slaves made up 20 percent of the U.S. population and 28 percent of the nation's labor force with 96 percent of all slaves being in the southern states.

\section{NATIONHOOD AND THE ISSUE OF SLAVE TRADING}

Following the successful war for independence from British rule, the Treaty of Paris of 1783 ceded all British land claims south of the Great Lakes to the interim confederation created by the former thirteen colonies. Thus, the original landmass of what would become the United States extended from the Atlantic Seaboard (except for Florida, which still belonged to Spain) to the Mississippi River. Becoming the unified nation that would occupy this space, however, was not an easy process. Among the many 
political issues and regional suspicions that had to be overcome was the issue of slavery.

Slavery was an inherited problem from colonial rule. In the North, slaves were few in number and of little economic importance. Hence, in one state after another slaves were emancipated by statutes until by 1804 they all had done so. But in the South, where virtually all of the slaves were to be found and where the extant agricultural economy was dependant on their use, the issue was far more complex. While few people sought to defend slavery in principle, many of the former southern colonies let it be known that they would not join the proposed union if slavery were prohibited. So resolution of this issue had to be deferred until after the ratification of the U.S. Constitution and the United States itself was established.

Likewise, the issue of slave trading also became involved in the founding of the nation. By the time of the Constitutional Convention, all of the former colonies had banned the importation of slaves from abroad except for Georgia and South Carolina. They threatened to refuse to join the proposed new nation before it was even established if the practice was banned. A compromise was reached by the drafters of the Constitution. Hence, the only provision in the U.S. Constitution that has anything even remotely to say about immigration pertained to the importation of slaves. ${ }^{5}$ Namely, slaves could continue to be brought into the country for twenty years - or until 1808-after which time Congress would have to decide the issue. With this compromise, the creation of the country became possible.

Subsequently, in December 1806, President Thomas Jefferson recommended to Congress that the importation of slaves be prohibited as of January 1, 1808 (i.e., the earliest possible date). Congress responded in late 1807 by passing such a ban.

This legislation, however, did not actually end slave trading, nor did it have any immediate impact on the institution of slavery. In fact, the demand for slaves increased markedly in the years after 1808. During the 1820 s, cotton became "king" and the modern cotton industry of the South began to develop. ${ }^{6}$ The number of slaves in the labor force grew from 893,602 slaves in 1800 to $3,953,760$ slaves on the eve of the Civil War in 1860. Most of the growth was the result of the natural reproduction of the slave population. Some was the result of land expansion during this period as slaves were included with the enormous amount of territory associated with the Louisiana Purchase of 1803 and with the annexation of Texas in 1845. But the continual import of slaves was also a factor in the subsequent growth of the South's own slave population. Since it was an illegal act, however, no official data exist as to how many slaves were imported after the practice became 
illegal in 1808. Ship manifests were regularly falsified to show cargoes other than the slaves that were actually aboard. It has been, however, estimated that at least 270,000 slaves-and probably more-were smuggled into the South from 1808 to $1861 .^{7}$

In other words, slave trading flourished despite the ban on the practice. The governmental agencies given responsibility for enforcing the importation ban (the Department of the Treasury, the U.S. Navy, and then the Department of the Interior) all had multiple duties to perform. Moreover, the funds appropriated by Congress for patrol of the long sea border of the southeastern United States were grossly inadequate. Outside of the South, there was general apathy by the public about the importance of addressing the illegal slave trade issue. It was seen to be a regional concern. As a consequence, slave trading did not end until slavery itself was abolished. This process began when President Abraham Lincoln in 1862 issued the Emancipation Proclamation, which freed the slaves as of January 1, 1863 in those states that seceded from the Union; it was completed after the war with the ratification of the Thirteenth Amendment to the Constitution in 1865 , which forbade the practice of slavery everywhere in the nation.

The effect of slavery on the composition of the labor force was, of course, primarily felt in the South. In 1860, the slave population accounted for 21 percent of the nation's labor force with 97 percent of the slave population being in the South. Some of the slaves worked in towns and cities of the South but most were tied to rural plantations. Agriculture remained overwhelmingly the industrial base of the entire southern economy and the dominant occupational source for most of the black labor force. ${ }^{8}$

\section{MASS IMMIGRATION BEGINS: THE SOUTH IS BYPASSED}

In the thirty years prior to the outbreak of the Civil War (roughly from the early 1830s and lasting until the late 1850s), the "first wave" of mass immigration from Europe began. Five million immigrants arrived over this time span. They were responding to an emerging demand for urban workers. The process of industrial diversification of production had begun earlier in the New England states. It was especially associated with the regional growth of the new manufacturing sector that began in earnest after 1815 . Cotton textiles became the nation's first major manufacturing industry. Originally, the employers of these factories sought to use women and children from the local communities as their workers. ${ }^{9}$ But by the 1830 s, they began to hire immigrants from Ireland and French-speaking Canada. Germany also became a major source of immigrants for the emerging demand 
for urban labor. Indicative of this industrial transformation is the fact that the percentage of the labor force of the states of the North and West employed in agriculture plummeted from 68 percent in 1800 to 40 percent in $1850 .{ }^{10}$

Thus, as industrialization was taking hold in New England and around the urban fringes of the upper Midwest along the shores of the Great Lakes, blacks still were trapped in the slave system of the South. As mentioned, black slave trading continued during the critical period, albeit illegally, so the "involuntary" immigration of blacks was also part of the "first wave" of mass immigration until the Civil War finally halted the practice.

Largely confined to the South, virtually all blacks were still linked to its regional economy. Although there were isolated instances where some iron, granite, and tobacco manufacturing occurred in the South, which used some slave labor, agriculture remained the mainstay of the southern industrial structure. Cotton farming was the dominant source of production and black employment. But other crops, such as tobacco, rice, and indigo, were also important and, increasingly, hemp and sugarcane became so too. Furthermore, cotton farming (and the use of slaves) shifted during these years from the Carolinas to the richer soil of the bottomlands of the Mississippi and Alabama and, still later, to Arkansas and Texas. In sharp contrast to the experiences of the rest of the country during these early years of the Republic, the percentage of the southern labor force employed in agriculture actually increased from 82 percent in 1800 to 84 percent in $1850 .{ }^{11}$

Thus, during these years prior to the Civil War, slavery was the force that kept blacks regionally confined and occupationally concentrated. Immigration contributed to the growing size of the black population in the South. But elsewhere, immigration served primarily as an alternative to seeking black workers (who could not respond to market forces anyhow due to the restrictive hold of slavery) or relying on native-born white workers (for whom the western frontier often served as a mobility lure).

\section{THE INDUSTRIALIZATION OF THE U.S. ECONOMY TAKES HOLD: THE SOUTH IS LEFT OUT}

The Civil War was not only a turning point in the nation's social history as regards to ending slavery. It was also the economic "break point" between "agricultural America" and "industrial America." 12 The prewar pace of diversification of the economies of the North and the West accelerated during the war and took off in the immediate decades that followed. Major physical improvements were made in transportation systems 
during and after the war. Large military contracts from the federal government during the war hastened the onset of mass production techniques that enhanced productivity in the years that followed. By the end of the nineteenth century, corporate domination of the business sector had taken hold and, through a wave of mergers, the scale of many production units was dramatically increased. The internal combustion engine was introduced as the twentieth century began, which revolutionized transportation and hastened the development of the petroleum industry. Thus, by 1920, manufacturing had replaced agriculture as the nation's largest employment sector. The preponderance of this vibrant and diverse activity occurred in the North and the West. The South, in sharp contrast, lay in physical ruin after the war and only slowly was it able to reconstruct its infrastructure and its industrial base. Its economy remained bound to agriculture.

In contrast, the North and West needed to enlarge its urban workforce during these years to meet this acceleration of demand for largely unskilled workers. Immigration from Europe and, to a far lesser degree, from Asia, became the chosen course. ${ }^{13}$ It was the strength of the "pull" factors of the U.S. economy rather than the "push" factors of conditions in their homelands that set this mass movement of people in motion. ${ }^{14}$ Ten million immigrants, mostly from Northern and Western Europe, entered between 1861 and 1890 (the "second wave" of mass immigration) and 16 million more, mostly from Eastern and Southern Europe, entered between 1890 and 1920 (the "third wave" of mass immigration).

It is instructive to note that during all of these years "the greatest direct beneficiary of the flow of immigrant labor was never agriculture though farming was our primary industry." 15 The economy of the South, of course, was still primarily agriculturally based and it was where most black workers were to be found. Throughout the latter half of the nineteenth century, the economic growth in the South was slow. For blacks, little changed in terms of their economic status. Slavery was replaced by sharecropping, which was essentially another form of bondage whereby credit was extended but the borrower's mobility was restricted until all debts were paid off. "Black codes" were enacted that regulated black conduct in day-to-day life. Most blacks in the rural South, therefore, were prevented from being able to leave the plantations where they had previously worked as slaves. As a consequence blacks "tended to be frozen to agriculture" throughout this era. ${ }^{16}$ The imposition of the infamous "Jim Crow" segregation laws in the 1890s and their enforcement during the years that followed served to complete the social marginalization process of blacks in the South. 
Thus, during these critical transition years of the American economy from its original heritage as a static agricultural society to its new era as a dynamic and industrially diverse economy, most native-born workers (black and white) who populated the nation's vast rural areas were left out. Most of these native born rural workers were living lives of poverty. They were also lacking in human capital endowments. But given the types of unskilled jobs that were being created at the time in the urban sectors outside the South, they were certainly as minimally qualified as were most of the immigrants who became the preferred alternative.

Most of these rural workers nationwide were whites but the most obvious source of surplus labor at the time was the black population who were still trapped in the South. The percentage of the black population living in the South in 1910 (90 percent) was essentially the same as it was on the eve of the Civil War fifty years earlier in 1860 (92 percent). Indeed, the famed black educator of the era, Booker T. Washington, made the status of black labor the central theme of his famous speech at the Atlanta Exposition of 1895. He pleaded with the assembled white industrialists not to look "to the incoming of those of foreign birth and strange tongue and habits." 17 Instead, he asked them to turn to native-born blacks, "who shall stand with you with a devotion that no foreigner can approach" and, by "interlacing our industrial, commercial, civil, and religious life with yours...[we] shall make the interests of both races one." ${ }^{18}$ His wise words-while cheered at the time-were ignored in practice. It would not be until immigration was cut off during World War I that blacks could finally migrate and compete for the new array of jobs being created in the urban North and West.

\section{“OPEN-DOOR” IMMIGRATION ENDS; BLACK OUT-MIGRATION BEGINS}

The outbreak of World War I in Europe in 1914 led to a rapid decline in immigration to the United States. It was no longer feasible for Europeans to leave as their governments were recruiting armies and fighting among themselves. Travel in many areas was impossible. Over 80 percent of the 5.7 million immigrants who entered the United States over the decade (i.e., from 1911 to 1920) arrived before the war, from 1911-1914; 10 percent came after the war was over in 1919 and 1920.

The cutoff of immigration from its primary supply source (Europe) and the simultaneous increase in the demand for domestic workers- to fill military orders for the government and to replace workers conscripted into military service-led to the most significant change in economic circum- 
stances that black Americans had yet experienced. Namely, they had the opportunity to move to urban areas outside the South. The chance was seized.

When World War I was over, there were immediate signs that another wave of European immigration was poised to commence. But attitudes and circumstances had changed in the United States. Geographically speaking, the continental frontiers had all been overcome. Moreover, the alleged benefits of mass immigration as a source of cheap and exploitable labor had given way to a recognition that there were also real costs that needed to be balanced off. Uncontrolled immigration had been found to generate unemployment, depress real wages, increase urban poverty, foster slum housing, and contribute to a variety of adverse health and safety conditions. ${ }^{19}$ Furthermore, there were widespread concerns that the "third wave" of mass immigration had been so diverse in its ethnic, racial, linguistic, and religious makeup and so immense in its scale that it was proving difficult, if not impossible, for the urban population to meld into a unified citizenry.

With widespread popular support, legislation was enacted to end almost a hundred years of continuous mass immigration. Efforts to screen out some immigrant groups had begun earlier on a small scale, but now legislation was passed to restrict the level of immigration. In 1917, the Immigration Act of 1917 had created the "Asiatic Barred Zone" which, in effect, banned all immigration from Asia; in 1921 legislation established a temporary annual ceiling of 358,000 immigrants from the Eastern Hemisphere (where most "third wave" immigration had originated) with discriminatory country quotas (favoring immigrants from Northern and Western European countries) until a more comprehensive piece of legislation was drafted. These efforts culminated in the enactment of the Immigration Act of 1924 (also known popularly as the National Origins Act). It established the annual ceilings on immigration at an even lower annual level of 154,000 persons from Eastern Hemisphere nations (which was essentially Europe). In addition, the legislation also set individual quotas for each country that was eligible to supply immigrants. These quotas were discriminatory in that much higher quotas applied to countries of Western and Northern Europe while much lower quotas applied to countries of Eastern and Southern Europe. Immigration from Asian countries had been essentially banned entirely by earlier legislation and restrictive agreements. Likewise, blacks were excluded from any computation of the population for the purpose of establishing future quota eligibility because they were considered by legislators to have been "involuntary immigrants." 20 Hence, there would be virtually no future immigration permitted from most 
African countries (except for token quotas given to some North African nations and some African colonies of European nations).

Clearly, the objective of the national origins system was to eliminate the foreign born as an important future element in the American population. Indeed, as a consequence of its adoption, the percentage of the U.S. population that was foreign born fell consistently from 14.7 percent in 1910 to its all-time historic low of 4.4 percent in 1965 when, as will be discussed, mass immigration (i.e. "the fourth wave") was accidentally revived.

Support for the imposition of these legislative restrictions on immigration in the 1920s came from virtually every quarter-business, labor, academia, and Protestant church leaders. Black leaders also joined in the chorus. A. Philip Randolph, who later would help lead the civil rights movement in the late 1950s and 1960s, was editor of the Messenger magazine (which promoted trade unionism and socialism) in the 1920s. In his editorials at this time, he wrote that the United States was suffering from "immigration indigestion" and he favored reducing immigration "to nothing." $\mathrm{He}$ not only supported "shutting out the Germans from Germany, the Italians from Italy...the Hindus from India, the Chinese from China," but he also included keeping out "the Negroes from the West Indies."

The response of blacks in the South to the opening was immediate. Black migration out of the South began in earnest in $1915 .{ }^{22}$ In 1910, over twothirds of all black Americans lived in rural areas (almost exclusively in the South). During the decade from 1911 to 1920, 369,000 blacks left the South; between 1921 and 1930 the number more than doubled (see Table 1). ${ }^{23}$ By 1930, 20 percent of the nation's black population lived outside the South, with 88 percent of these persons concentrated in large urban centers. ${ }^{24}$

\section{A NEW TREND IS BORN: DECLINING IMMIGRATION LEADS TO INCREASING BLACK MIGRATION OUT OF THE SOUTH}

The migration trend that began with World War I became one of the nation's most important economic and social movements of the twentieth century. For black Americans, it was the most significant such trend. As articulated by Raymond Frost and shown in Table 1, "there is a competitive relationship between immigration and black migration out of the South.... [W]hen the rate of immigration declines, black migration to the North and West increases; when the rate of immigration increases, black migration declines." 25 
The reception by those outside the South to the arrival of blacks to their cities was anything but hospitable. As historian Arthur Link described the reception in the North and Midwest of blacks into their already existing urban slums, "they became the object of the suspicion and hatred of white unskilled workers, most of them immigrants themselves." ${ }^{26}$ Indeed, full scale racial riots - often pitting recent white immigrants versus recent black migrants-broke out in a number of northern and Midwestern cities beginning in East St. Louis in 1917 and continuing intermittently for several decades. ${ }^{27}$

But with immigration controlled for the first time in American history, black migration soared. In each of the decades of the 1940s, 1950s, and 1960s, black out-migration from the South was greater than that of the entire thirty-year period from 1910 to 1940 , when it all began.

The economic effect of out-migration on blacks was to widen their industrial and occupational choices. Rural black workers, whose heritage had largely been farm work, joined with similarly situated rural white workers in a mass movement to the nation's urban economy. Over the decade of the 1920s, 6 million persons moved from the farms to the cities. It was the first decade in the nation's history that the rural population actually sustained a net loss. With mass immigration finally restrained, native-born rural workers were free at last to seek the wider economic opportunities afforded by the rapidly expanding urban labor market. Arthur Link has described this rural to urban migration as "one of the most important changes in the American social fabric." ${ }^{28}$ Given their inadequate educational preparation and lack of skill training, most of these newly urbanized blacks had to start on the bottom rung of the job ladder. But at least they could finally enter competition. Fortunately, most of the expanding urban jobs in this era did not require much in the way of job preparation-if one could get hired.

\section{WORLD WAR II AND ITS AFTERMATH: LOW IMMIGRATION AND THE CREATION OF A WINDOW OF OPPORTUNITY}

The depression decade of the 1930s was a staggering blow to the economic well being of American workers of every description. But as shown in Table 1, the number of blacks leaving the South during these years slowed from its pace in the 1920s but it did not stop. The economic consequences of the outbreak of World War II in the early 1940s, on the other hand, shocked the economy out of its doldrums. Black out-migration from the South soared. By 1950, one-third of the black population lived north of the Mason-Dixon line. 
With over 11 million men drafted into military service during the war years and with dramatic increases in related military production levels as the result of sharp increases in government spending, it was imperative that civilian workers be found to meet the demand for labor. Immigration levels, which had been low since the late 1920s, continued to be so. Hence, national employment policy was forced to tap domestic reserves that had been hitherto ignored, underutilized, or marginalized. Rural workers were one source of surplus labor and the rural South in particular was a rich pool of potential manpower. Blacks poured out of the South-both into military service and to the domestic job opportunities in the North and West. Others who responded were women, older workers, youths, and disabled workers. Thus, despite the withdrawal of millions of working-age men during the war into military service, the nation's civilian labor force still increased by over 5 million workers between 1941 and 1945.

The tight labor market of the early 1940s provided the chance for black leaders to attack broadside the issue of racial discrimination in employment. A. Philip Randolph and other black leaders threatened in 1940 to organize a "march on Washington" to publicize the issue of employment discrimination in all regions of the country. President Franklin Roosevelt responded in 1941 by issuing executive orders banning discrimination by holders of federal contracts - of whom there were many at the time-and creating a federal committee to investigate charges of employment discrimination. These actions are considered "milestones" in the path that would lead to the passage of the historic Civil Rights Act of 1964 a generation later. Thus, the labor shortages of this period and the lack of an immigrant alternative for employers were both crucial contributors to the launching of the economic plank (i.e. the equal employment opportunity goal) of the broader civil rights agenda that would come to a head in 1964.

\section{THE CIVIL RIGHTS MOVEMENT SPILLS OVER TO IMMIGRATION REFORM}

In the early 1960s, the major domestic issue was not immigration reform. It was civil rights policy. But their destinies became intertwined. The civil rights movement had evolved into an activist stage that used demonstrations, marches, and boycotts to protest in non-violent manners the perpetuation of overt segregation against black citizens in the South. The primary focus was on the abuses of social dignity (i.e., segregated public facilities) and the denial of political rights (i.e., restrictions on the right to vote). 
The culmination of these protests came with the passage of the Civil Rights Act of 1964. In the wake of the assassination of President John F. Kennedy in November 1963, the political logjam that had blocked Kennedy's attempts to address a multitude of domestic policy concerns was finally broken. The new president, Lyndon B. Johnson, was one of the most politically astute men to ever hold the position. After assuming office, he announced his intention to enact a broad social program under the rubric of building "The Great Society." Virtually all of this ambitious domestic reform agenda were subsequently enacted. Moreover, persons dedicated to the accomplishment of these objectives were appointed to head the various government agencies to implement this social agenda.

One of the reforms pertained to the subject of immigration and it was directly linked to another: civil rights. For to invoke in legislation the explicit principle that overt racism could no longer be tolerated in the ways citizens treated each other implicitly meant that there could no longer be overt discrimination in the nation's laws that governed the way future citizens would be considered for immigrant admission. Secretary of State Dean Rusk made this linkage explicit in testimony before Congress in support of immigration reform in August, 1964: "The action we urge... is not to make a drastic departure from the long-established immigration policy, but rather to reconcile our immigration policy as it had developed in recent years with the with the letter of the general law." 29 It was the passage of the Civil Rights Act of 1964, therefore, that created the political climate needed to legislatively end the discriminatory national origins system the following year with the adoption of the Immigration Act of $1965 .^{30}$

There was, however, an ironic twist to the linkage of civil rights legislation to immigration reform. While both issues came to the forefront of the national agenda because of political and social concerns, both also had significant economic consequences with regard to their labor market impacts. The economic aspects, however, were not the focus at the time nor was the possibility foreseen seen that these two policy pursuits could conflict with each other.

The Civil Rights Act of 1964 contained Title VII, which prohibited discrimination in employment on the basis of race, color, gender, religious belief, or national origin. When it actually went into effect on July 1, 1965, its terms applied to employers, labor unions, and private employment services. As opposed to the other sections of the Act that focused on social and political practices largely occurring in the South, equal employment opportunity was an economic issue and it had nationwide implications. 
Within months after its enactment, however, a rash of civil disturbances broke out in urban areas across the nation. Over the ensuing years, there were many more. To identify the causes of these riots, the National Advisory Commission on Civil Disorders was established. It issued its historic report in March 1968. It found that the issue of employment discrimination was a far more complex issue than the drafters of the Civil Rights Act had earlier envisioned. ${ }^{31}$ Public policies were needed to overcome the past denial of job opportunities and to provide employment preparation. They would entail far more programmatic action and public funds than the mere issuance of a ban on future discriminatory behavior as stated by Title VII.

If past patterns of employment for black Americans were not to be replicated in the future, affirmative action policies would be needed to reach out to already qualified blacks for jobs. But in far too many cases, blacks were unqualified for the high-skilled, high-income jobs that were expanding in number. Too many blacks were disproportionately concentrated in the low-skilled, low-income occupations and industries where jobs were declining due to the advent of new computer technology. To change these employment patterns, it would be necessary to address the extensive human capital deficiencies of blacks that were the accumulated legacy of centuries of stifled aspirations, unequal educations, and inadequate training opportunities. The civil disorders, after all, had occurred at a time when full employment prevailed (i.e., the national unemployment rate was in the mid-3 percent range). But, because the black population had become highly urbanized, and disproportionately concentrated in central cities, unemployment in these areas remained much higher than the overall national unemployment rate. Moreover, the black labor force was beset with inordinately high incidences of working poor, discouraged workers, under-employed workers, involuntary part-time workers, and female-headed households. There was no thought at the time that many of these same urban labor markets where blacks were concentrated were about to receive a mass infusion of new immigrants - most of whom would themselves be from minority groups and many of whom also had significant human capital deficiencies.

The Advisory Commission boldly stated that the nation had unfinished business to address if it was serious about fulfilling the ideals of the Civil Rights Act. It was in the national interest to upgrade the capabilities and expand the utilization of the available pool of black workers. Otherwise, many blacks would be condemned to lives in a permanent underclasswith all of the attended hardships of welfare dependency, crime, alcoholism, prostitution, and irregular work habits that scar the individuals involved 
and burden society. But with respect to blacks, there was also a clear moral imperative that recognized that their collective fate had been greatly influenced by external institutional forces over which they only had marginal control. ${ }^{32}$ A programmatic agenda, aimed at bridging the past period of denial of opportunities and a future period of equal opportunity, was required. What was anticipated was that there would be a concerted effort made over the ensuing decade to give priority to the urgent needs of black Americans.

Who could have foreseen that immigration reform was about to become a new example of the institutional policies adversely affecting blacks that the Advisory Commission had condemned? In earlier times, immigration policy had kept blacks in the rural South after slavery ended by providing an alternative source of workers to meet the industrial expansion needs of the North and West. In the late twentieth century, immigration policy once more provided an alternative to providing the momentum for the pursuit of inclusive policies needed to alter the economic status of blacks in U.S. society. It also sparked pressures for blacks to migrate back to the South beginning in the late 1970s.

\section{THE IMMIGRATION ACT OF 1965: INTENTIONS VERSUS OUTCOMES}

The intent of the supporters of immigration changes in the early $1960 \mathrm{~s}$ was best expressed by President John Kennedy, who initiated the process. He stated that, "the most urgent and fundamental reform I am recommending relates to the national origins system of selecting immigrants." ${ }^{33} \mathrm{He}$ recommended that it be replaced by a system that would give "the highest priority" to "the skills of the immigrant and their relationship to our need" and it should not "matter where they are born." ${ }^{34}$ His proposal did not call for any significant increase in the level of immigration. In contrast to earlier times, he specifically pointed out that "we no longer need settlers for virgin lands." 35 Thus, he reiterated that, "the clash of opinion arises not over the number of immigrants admitted, but over the test for admission." 36

On July 23, 1963, the administration formally forwarded its immigration reform proposal to Congress. It sought to change the character of existing immigration policy and was not intended to increase the level of immigration. Indeed, there were widespread fears in Congress at this time that increasing the number of immigrants in general would lead to adverse employment and wage effects in the labor market.

Following the assassination of President Kennedy, as previously indi- 
cated, President Johnson took up the immigration reform banner. It was not until early 1965, however, that Congress responded to the administration's proposals. The original bill had called for a five-year phase-out of the national origins system and the immediate termination of the last traces of discrimination against Asian immigration. In place of the use of national origin as the primary admission criteria, the bill proposed that 50 percent of admissions would be based on the preferences given to immigrants who had skills and work experience that were currently in need by the U.S. economy. The other half would be granted on the basis of various adult family relationships of would-be immigrants to U.S. citizens or permanent resident aliens. As before, the preferences would only apply to Eastern Hemisphere immigrants.

Given the times, political agreement to end the overt racism of the national origins system was relatively easy. Finding common ground for a replacement criterion was much more difficult. From the onset, Congress let it be known to the Johnson administration that any new legislation in this area must contain two new components.

First, there must also be a ceiling on Western Hemisphere immigration. Congress feared that with the extraordinarily high population-growth rates in Latin America, the absence of a limit would lead to an uncontrolled influx of immigrants from this region in the near future. Hence, the inclusion of a ceiling on the Western Hemisphere in the enacted bill "was a necessary quid pro quo in exchange for abolishment of the national origins quota system." 37 Thus, an annual ceiling of 120,000 immigrants from the Western Hemisphere was included in the final version of the legislation.

Secondly, congressional leaders felt that the labor certification requirements for non-family related immigrants had to strengthened. Thus, under the Immigration Act of 1965, immigrants from Eastern Hemisphere nations who were admitted on any basis other than family reunification or refugee status must receive certification in advance from the U.S. Department of Labor that their presence would not adversely affect employment opportunities or the prevailing wage and working conditions of citizen workers.

Under other provisions of the Immigration Act of 1965, an annual ceiling of 170,000 visas was imposed on immigration from all the nations of the Eastern Hemisphere. This figure was slightly higher than the hemispheric limit in effect since the 1920s.

To determine which individuals were to be admitted within the framework of the numerical ceiling set for the Eastern Hemisphere, a sevencategory preference system was created. The new preference system relied 
largely on family reunification as its priority concern. "Immediate family" relatives (i.e., persons defined under the Act as being spouses and minor children although it did add parents of U.S. citizens over the age of twentyone to this category) were not counted as part of the hemispheric or the individual country ceilings. Thus, the term "family reunification" in this case referred to the admission of adult children of U.S. citizens over the age of twenty-one; spouses and unmarried children of permanent resident aliens; and adult brothers and sisters of U.S. citizens. Collectively, they accounted for 74 percent of the annually available visas. Thus, family reunification became the "cornerstone" of U.S. immigration policy and it has remained so ever since. ${ }^{38}$ During the legislative process, Congress reduced the occupational preferences share of the annually available visas to no more than 20 percent. The remaining visas, 6 percent, were reserved for a new admission category: refugees.

These changes in the priorities of the admission system were made in response to the lobbying of groups that were strongly opposed to abolition of the national origins system. Recognizing that they could not block the reform drive on this fundamental issue, they sought to make the changes in the admissions criteria more symbolic than real. These groups and their congressional sympathizers believed that by stressing family reunification it would be possible to retain essentially the same racial and ethnic priorities that the national origins system had fostered even if this mechanism itself was abolished. It seemed unlikely, for instance, that many persons from Asia, Africa, or from southern or eastern Europe would be admitted under the new system because the prohibitions imposed during the national origins era had prevented the entry of many of their relatives for the past forty years. Conversely, those favored over the past forty years would most likely have the most living family relatives who could use their citizenship status to admit others like them.

Thus, the principle of family reunification, which political supporters have strongly defended in subsequent years, does not rest on a strong moral foundation. It should not be overlooked that, aside from making nepotism the dominant admission criterion of the legal immigration system, family reunification was based on the nefarious belief that it would perpetuate past discrimination into the future but under a more politically acceptable mantle. As Congressman Emanuel Celler (D-N.Y.) — the co-sponsor of the legislation-stated on the floor of Congress during the final debate on the bill in which he urged passage, "there will not be, comparatively, many Asians or Africans entering the country...since the people of Africa and Asia have very few relatives here, comparatively few could immigrate from 
those countries because they have no family ties to the U.S." ${ }^{39}$ Thus, it was clearly understood by Congress that immigration reform was not intended to increase the size of the nation's black population.

Likewise, there were other things that were promised that would not happen if this bill passed. Senator Edward M. Kennedy (D-Mass.), floor manager of the bill in the Senate, reiterated during the final debate on the pending legislation: "this bill is not concerned with increasing immigration to this country, nor will it lower any of the high standards we apply in the selection of immigrants." ${ }^{40}$ Earlier, in a committee session, he stated that "our cities will not be flooded with a million immigrants annually;" that "the ethnic mix of this country will not be upset;" and "it [the pending bill] would not cause American workers to lose their jobs." ${ }^{41}$ But, as will be seen, the new law did, in fact, set into motion the process over the ensuing years whereby none of his assumptions proved to be valid.

In the 1970s, two important amendments were added to the Immigration Act of 1965. Following the imposition of the ceiling on Western Hemisphere immigration, a massive backlog of applications for visas quickly developed from persons living in Latin American nations (especially Mexico). Accordingly, in 1976 an amendment was adopted that extended the seven-category preference system and the labor certification requirements to would-be applicants from Western Hemisphere nations as well. The effect of this extension was that, for the first time, it would be difficult for any person from the Western Hemisphere who did not fit into one of the seven preference categories to enter legally. Another amendment in 1976 extended the annual ceiling of 20,000 immigrants from any single nation in the Western Hemisphere that had been applied to nations in the Eastern Hemisphere in 1965.

In 1978 another amendment was added to the Immigration Act of 1965, which finally gave the United States the unified immigration system that reformers had sought for over three decades. The two separate hemispheric ceilings were merged to give the nation a single worldwide quota that was set at 290,000 visas a year.

\section{THE REVIVAL OF MASS IMMIGRATION}

Despite assurances that the phenomenon of mass immigration would not be revived from the nation's distant past, the Immigration Act of 1965 had precisely this result. As can be seen from Table 2, the "fourth wave" of mass immigration can be dated to its passage. From 1930 until 1965, the foreign-born population level declined in absolute numbers; as a percent- 
age of the population, the foreign born had been declining since 1910. In 1965 there was no reason to expect that either of these dominant trends would be reversed. But, as Table 2 shows, they were-and significantly so.

The precise factors that led to that accidental revival of mass immigration are too complex to describe here. ${ }^{42}$ In a nutshell, however, they are: an explosion in illegal immigration; refugee entries have soared far beyond anticipated levels as has the arrival of tens of thousands of political asylum applicants each year after an asylum policy was added in 1980; the emphasis on family preference admission has led to far greater numbers of "immediate relatives" (whose numbers are not restricted) than anticipated; and the liberalization of various non-immigrant (i.e., temporary foreign worker) visa provisions has led to far more such foreign job seekers than was predicted. As these unexpected results have been revealed, the responses of subsequent Congresses has been either to ignore these outcomes; or to pass half-hearted and ineffective restrictive measures (as in the case of attempts to address illegal immigration); or to take counter-productive steps based on false premises (i.e., the expansion of legal immigration in 1990 based on the assumption that illegal immigration has been significantly reduced by legislation in 1986).

The impact of the "fourth wave," however, is far more than the mere increase in numbers. Unlike the previous three "waves" where the preponderance of the immigrants was from Europe, the "fourth wave" is unique in that most of the immigrants are non-European and non-Africans. In 2000, 51 percent of the foreign born population of the United States were from Latin America; 25.5 percent from Asia. In sharp contrast, only 15.3 percent were from Europe and 2.5 percent were from Africa. ${ }^{43}$ Given these shifts in the countries of origin, it is not surprising that the racial composition of the foreign born population in 2000 has been dramatically altered. ${ }^{44}$ Blacks were 13.5 percent of the native-born population but only 7.8 percent of the foreign-born population while non-Hispanic whites were 75.9 percent of the native population but 24.8 percent of the foreign population. On the other hand, the major gainers were the Hispanic population (of any race) who were only 8.1 percent of the native born population but 45.2 percent of the foreign-born population; and the Asian population who were only 1.7 percent of the native-born population but 23.6 percent of the foreign-born population.

No racial group, therefore, has been more adversely affected than has the black population by the shift in source countries that has occurred since 1965. Black immigration (mainly from Africa and the Caribbean Islands) represents the smallest component by far of the foreign-born population. 
Indeed, primarily as a consequence of post-1965 immigration, Hispanics (of any race) became in 2003 the nation's largest and the most rapidly growing minority group. But the issue is more than one of numbers; it also pertains to qualitative labor force characteristics in a post-1965 U.S. labor market convulsive with change.

\section{MASS IMMIGRATION AND THE “NEW” ECONOMY}

While immigration policy in the post-1965 years has affected the size and composition of the supply of labor, the demand for labor has also sustained a metamorphosis these same years from anything ever experienced before. In the three earlier "waves" of mass immigration, the economy needed large numbers of essentially manual workers. It made little difference whether they had skills, were educated, or spoke English. In most cases, the immigrants had few human capital attributes. But in the post1965 era, the advent of computer technology and the globalization of trade have caused a diminishment in the demand for low-skilled workers while the supply of low-skill jobs (especially in manufacturing) has been reduced. Conversely, the economy has entered a new developmental phase in which the expanding employment opportunities have been predominantly in the information and service producing sectors. ${ }^{44}$ By 2001,81 percent of the non-agricultural labor force of the nation was employed in service sector industries. The manufacturing sector, which was the largest employment sector from the 1920s until the mid-1950s, had fallen to fourth place (out of a total of nine non-agricultural industrial groupings) by 2001 in terms of employment. These industrial shifts have also affected occupational changes (a shift in white collar jobs) and geographic shifts (a decentralization of service jobs as opposed to the tendency to the concentrate jobs when goods producing dominated). Thus, the labor force since 1965 has been in a state of radical transformation. Over these same years the supply of labor has grown dramatically due to the demographic positioning of the "baby boom" generation, the unexpected mass entry of women into the paid-sectors of the economy and, of course, the return of mass immigration to the American experience. Against this backdrop of extensive changes, the new era of equal employment opportunity for blacks was also launched in 1965.

It is unfortunate that the only one of these forces of change that is totally subject to public policy determination-mass immigration-has been allowed to evolve since 1965 without any accountability for its economic consequences. Immigration policy over these years has been the product of 
an on-going series of dubious political compromises. As a consequence, it now consists of a hodgepodge of ineffective, counter-productive, and special interest provisions. In 1997, the U.S. Commission on Immigration Reform (CIR), chaired by the late Barbara Jordan for most of its life, concluded, "our current immigration system must undergo major reform" and it requires "a significant redefinition of priorities." "45 Among CIR's many recommendations were that the annual level of immigration be reduced by over one-third; that all of the extended family admission categories be eliminated; that no unskilled adults be admitted as legal immigrants; that refugee admissions be capped in number; and that every effort be made to stop the entry of illegal immigrants.

For present purposes, the significance of the nation's prevailing immigration policies has been to produce an influx of disproportionately unskilled and poorly educated into many of the nations largest urban labor markets (and, in selective cases into certain rural labor markets.) In the year 2000, one-third of the adult foreign-born population had less than a high school diploma and another one-quarter had only a high school degree. ${ }^{46}$ Moreover, 95 percent of the foreign-born population lived in metropolitan areas (as opposed to 79 percent of the native born) with 50 percent living in central cities in $2000 .{ }^{47}$ As for the jobs that immigrants hold, they are disproportionately employed in service occupations (19.2 percent); operators, fabricators, and laborers (18.7 percent); and farms, forestry, and fishing (4.5 percent) ${ }^{48}$

\section{THE “FOURTH WAVE” OF IMMIGRATION: ITS RELEVANCE TO BLACK AMERICANS}

In far too many ways, the indicators describing the foreign-born population closely resemble those of black Americans, which suggest the probability of competition in the labor market. For the black population too is disproportionately unskilled, concentrated in the central cities of metropolitan areas, and employed in low-skilled occupations. In 2001, 20.6 percent of adult blacks over the age of twenty-five were without a high school diploma; in addition, another 34.4 percent of blacks had only a high school degree. ${ }^{49}$ As for urban concentration, 87.5 percent of the black population lived in metropolitan areas with 52 percent of all blacks living in central cities. ${ }^{50}$ With respect to occupational patterns, 21.5 percent of blacks were employed in service occupations; 18.1 percent were operators, fabricators, and laborers (almost one-third of all black males were employed in this occupation); and 1.1 percent in farming, forestry, and fishing. 
In terms of geographic concentration in 2000, 26 percent of the foreignborn population resided in the South (the highest such percentage in U.S. history - with most of this increase occurring since 1990) while 55 percent of the black population did so. ${ }^{51}$ Unlike the earlier waves of mass immigration, a substantial number of the "fourth wave" is now living and working in the South. Indeed, Florida and Texas rank third (18.4 percent) and fifth (12.2 percent) respectively in terms of the proportion of their population who were foreign born in 2000. But the foreign-born population is also rapidly increasing in North Carolina, South Carolina, Georgia, and Alabama, which is without precedent. ${ }^{52}$

By the same token, the greatest growth in size of the foreign-born population has been outside the South, which is once more affecting the internal migration patterns of the black population. As discussed earlier, the black population did not migrate out of the South until the end of the "third wave" of mass immigration (i.e., the outbreak of World War I). Throughout the rest of the twentieth century (as shown in Table 1), there was a net migration out of the South up until the 1980s (when the "fourth wave" of mass immigration was in high gear). But beginning in the late 1970s, the pattern reversed itself. ${ }^{53}$ Between 1990 and 1996, for instance, the net migration of blacks to the South was $368,000 . .^{54}$

There are, of course, many factors that influence internal migration of the nation's domestic population. But that does not lessen the fact that international immigration into specific labor markets affects the internal mobility decisions of native-born workers. Indeed, research on contemporary labor mobility has found that native-born workers are less likely to migrate to urban areas where immigrants are concentrated..$^{55}$ Furthermore, foreign-born workers are less likely to move out of states where they are concentrated than are native born. ${ }^{56}$ Both features cause an accentuation of the impact of immigration in those urban labor markets where immigrants are concentrated. As economist Lawrence Katz has found, "there is now evidence that where immigrants are going, natives are leaving," because the arrival of more unskilled immigrant workers means lower wages and fewer low-end jobs for those who were originally there. ${ }^{57}$ In those urban cities in California that have experienced significant increases in immigration, for example, there has been a "flight" of low-income, poorly educated citizen workers out of their former communities to the outer fringes of their metropolitan areas or to other states. ${ }^{58}$

It is likely, therefore, that the fact that more blacks are migrating to the South as the twenty-first century begins than are moving out is due to the extensive immigration into urban labor markets in the North and into the 
coastal states of the South since 1965. But as immigrants have since the 1990s also been moving into the South, there is now nowhere else for blacks to go. They too will have to confront the reality of the consequences of the nation's unguided and largely unregulated flow of mass immigration. But at least in the South, the black population is significant in size and well established in its presence to meet the challenge.

Lastly, there is the issue of employment discrimination by the new immigrants against black Americans. With the inordinate emphasis given to family reunification in the post-1965 legal immigration system, it is not surprising that most of the new immigrants settle in the same geographic labor markets as have their relatives whose family ties were the basis for their admission. Kinship, therefore, rather than labor market needs, is the primary basis for locational settlement. The effect is that most new immigrants settle in central cities of a selected number of metropolitan areas where earlier immigrants from the same ethnic background have established enclaves. ${ }^{59}$ The result is that ethnic networking is often a major feature of the hiring process in these labor markets. ${ }^{60}$

Ethnic network hiring was a distinguishing feature of the urban labor markets of the earlier three waves of mass immigration. Since the passage of the Civil Rights Act of 1964, hiring practices are supposed to be changed so that it is illegal to hire (or to exclude) job applicants on the basis of their national origin. But such practices have again become common in those urban labor markets where immigrants have congregated. The casualties often are the native-born citizens who also reside in these cities (especially black Americans) who are denied the opportunity to compete for such jobs on an equal access basis. As one study in New York City found, "there are tens of thousands of jobs in New York City for which the native born are not candidates." 61 The reason, according to the study, is that "ethnic hiring networks and the proliferation of immigrant-owned small businesses in the city have cut off open-market competition for jobs." ${ }^{2} 2$ New York City, it should be noted, has the largest black population (2.3 million persons in 2000) of any city in the country.

Likewise an investigative report by the Wall Street Journal in 1995 found that in Los Angeles "many immigrant bosses are refusing to hire the nation's largest minority" (i.e., American-born blacks) for entry-level jobs in their enterprises. ${ }^{63}$ These immigrant entrepreneurs feel that immigrants are "more dependable" because they are "not inclined to complain about low wages and lousy working conditions;" they are "unaware of labor laws;" and that blacks "don't mix well with workers of other backgrounds." 64 It was reported that "it's like an unwritten law:" immigrant employers "won't hire 
blacks." ${ }^{65}$ With immigrant-owned enterprises accounting for about onequarter of all low-wage jobs in these cities, a significant portion of the entry-level jobs in these cities are essentially off-limits to native-born black job seekers. The report found that the same pattern of exclusionary hiring practices characterized the behavior of other immigrant-owned enterprises in higher paying industries-like electronics. ${ }^{66}$

The research in rural labor markets where immigrant labor is found has also noted widespread use of ethnic networking in the hiring process. ${ }^{67}$ As in urban areas, the practice limits job opportunities for native-born workers for these rural jobs.

Given the racial tensions in many communities between citizens (especially black Americans) and post-1965 immigrants, the need for corrective equal employment opportunity enforcement is long overdue.

\section{CONCLUDING OBSERVATIONS}

In terms of immigration policy, the United States began the twenty-first century just as it did the twentieth century: in the throes of another period of mass immigration. As a consequence, immigration is once again a significant influence on the nation's labor market in general and the well being of black Americans in particular.

The most obvious impact is the direct effect. No racial grouping receives fewer immigrants than does the black community. Consequently, in relative terms, other groups increase in number disproportionately to blacksa fact that has significant political implications. Furthermore, the tendency of the black population and the foreign-born population to both concentrate in a select number of metropolitan areas (e.g., New York, Chicago, Detroit, Los Angeles, Philadelphia, Houston, Miami, Washington D.C.) means that for about one-third of the black population there is direct economic competition, for jobs, housing, and social services.

But there are also indirect effects that are the cumulative consequences of four decades of mass immigration. Most of the foreign-born population who have entered since 1965 are also minority group members themselves. Since so many recent immigrants are unskilled, policymakers no longer seem to feel any urgency about the special problems faced by unskilled black workers. The consequences have been unfortunate. Black politicians and community leaders, who in the past were in the vanguard of advocating for restrictive and enforceable immigration policies, are not critics of the status quo of the contemporary era. They have felt the need to form alliances with these other groups who favor large-scale and loosely enforced 
immigration policies. Immigration expert David North has explained the seeming paradox. Focusing on the U.S. Congress-since immigration policy is exclusively a federal responsibility-North has observed

Black members of Congress, who might be expected to defend the interests of their often low-income constituents against competition with newly-arrived illegal immigrant worker, do not do so. The members of the Black Caucus, identifying with the members of the Hispanics Caucus, routinely support the Hispanics position on immigration issues. The politics of the chamber, in short, are more important to these Black Congressmen than the politics of the constituency. ${ }^{68}$

Thus, the politics associated with the "rainbow coalition" have led most black politicians to remain silent on the chronic need for comprehensive immigration reform in hope of gaining support for pet programs and of receiving influential appointments. But immigration policy has long-term implications that have been shown to be adverse to the economic interests of black Americans. Unless policy changes are forthcoming-such as those suggested by the Jordan Commission - the pace of progress for black citizens and workers will be hampered. For as the Emperor Napoleon wisely said, "policy is destiny."

\section{NOTES}

1. For an overview of the issue of mass immigration-its characteristics, causes, and consequences - see Vernon M. Briggs, Jr., Mass Immigration and the National Interest: Policy Direction for a New Century, third edition (Armonk, N.Y.: M.E. Shape, Inc., 2003).

2. See Ekiu v. United States, 142 U.S. 651 (1892); Henderson v. Mayor of the City of N.Y., 92 U.S. 259 (1876); Lung v. Freeman, 92 U.S. 276 (1876).

3. Stanley M. Elkins, Slavery, (New York: Grosset and Dunlop, 1959), p. 38.

4. Ibid., p. 49.

5. U.S. Constitution Article I, Section 9, Subsection 1.

6. W.E.B. DuBois, The Suppression of the African Slave Trade to the United States (New York: Schocken Books, 1969), pp. 152-153.

7. Stanley Lebergott, Manpower in Economic Growth (New York: McGraw Hill, 1964), p. 20.

8. Ibid,, p. 102.

9. Barbara Tucker, Samuel Slater and the Origins of the American Textile Industry (Ithaca: Cornell University Press, 1984).

10. Lebergott, op. cit., p. 102.

11. Ibid.

12. Vernon L. Parrington, The Beginning of Critical Realism in America (New York: Harcourt, Brace, (1930), p. 7. 
13. See Briggs, op. cit., chapters 6 and 7; and Lebergott, op. cit., pp. 24-29.

14. Lebergott, op. cit., p. 40.

15. Ibid. p. 28.

16. Ray Marshall, The Negro Worker (New York: Randon House, 1967), p. 11.

17. Booker T. Washington, "The Atlanta Exposition Address," in Three Negro Classics (New York: Avon Books, 1965), p. 147.

18. Ibid., p. 148.

19. For a summary of these findings, see U.S. Immigration Commission, $A b$ stracts of the Reports of the U.S. Immigration Commission (Washington D.C.: U.S. Government Printing Office, 1911), Volume 1; see also discussion of the Report in Briggs, op. cit., pp. 81-82.

20. Desmond King, Making Americans: Immigration, Race, and the Origins of the Diverse Democracy (Cambridge, Harvard University Press, 2000), pp. 39-49, 152, and 163-164.

21. See quotations contained in Daryl Scot, "Immigration Indigestion: A. Phillip Randolph, Radical and Restrictionist," Backgrounder (Washington D.C.: Center for Immigration Studies, 1999), p. 3.

22. Arthur S. Link, American Epoch (New York: Alfred A. Knoff, 1956), p. 297.

23. Raymond Frost, "Immigration vs. Black American Migration," Challenge: A Magazine of Economic Affairs (November-December, 1991), p. 68.

24. Link, op. cit., p. 297.

25. Frost, op. cit., p. 28.

26. Link, op. cit., p. 244.

27. Hugh D. Graham and Ted R. Gurr, Violence in America (New York: Bantam Books, 1969), pp. 401-406.

28. Link, op. cit., p. 297.

29. "Statement by Secretary of State Dean Rusk before the Subcommittee on Immigration of the U.S. Senate Committee on the Judiciary," as reprinted in the Department of State Bulletin, "Department Urges Congress to Revise Immigration Laws" (August 24, 1965), p. 276.

30. U.S. Congress, House of Representatives, Committee on the Judiciary, 104th Congress, 1st Session, Immigration and Nationality Act, tenth edition (Washington, D.C.: U.S. Government Printing Office, 1989), p. 589.

31. National Advisory Commission on Civil Disorders, Report of the National Advisory Commission on Civil Disorders (New York: Bantam Books, 1968).

32. Ibid., p. 203.

33. John F. Kennedy, A Nation of Immigrants, Revised Edition with an Introduction by Robert F. Kennedy (New York: Harper and Row, 1964), p. 102.

34. Ibid., p. 103.

35. Ibid., p. 80 .

36. Ibid.

37. U.S. Congress, Senate Committee on the Judiciary, 96th Congress, 1st Session, U.S. Immigration Law and Policy: 1952-79 (Washington, D.C.: U.S. Government Printing Office, 1979), pp. 234-42.

38. U.S. Congress, U.S. House of Representatives Select Committee on Population, 95th Congress, 2nd Session, Legal and Illegal Immigration to the United States (Washington D.C.: Government Printing Office, 1978), p. 10.

39. U.S. Congress, House of Representatives, Congressional Record, 89th Congress, 1st Session (August 25, 1965) (Washington D.C.: U.S. Government Printing Office, 1965), pp. 21, 758.

40. U.S. Congress, Senate, Congressional Record, 89th Congress, 1st Session 
(September 17, 1965) (Washington D.C.: U.S. Government Printing Office, 1965), pp. 24, 225.

41. "Statement of Senator Edward Kennedy," Hearings on S. 500, 89th Congress, 1st Session, (August 25, 1965) (Washington D.C.: U.S. Government Printing Office, 1965), pp. 1-3.

42. For detailed discussion of the factors that triggered the revival of mass immigration, see Briggs, op. cit., chapter 10.

43. U.S. Bureau of the Census, Profile of the Foreign-Born Population in the United States: 2000 (Washington D.C.: U.S. Bureau of the Census, 2001), pp. 23206; 10. (The remainder of the foreign born were from North America, Australia Oceania.)

44. For elaboration, see Briggs, op. cit., chapter 11.

45. U.S. Commission on Immigration Reform, Legal Immigration: Setting Priorities (Washington D.C.: U.S. Commission on Immigration Reform, 1994), p. i of letter of transmittal.

46. U.S. Bureau of the Census, op. cit., p. 36.

47. Ibid., p. 17.

48. Ibid., p. 40.

49. U.S. Bureau of the Census, The Black Population in the United States: March 2002 (Washington D.C.: U.S. Government Printing Office, 2003), p. 4.

50. U.S. Department of Labor, Employment and Earnings (Washington D.C.: U.S. Government Printing Office, 2002), p. 172.

51. Ibid., p. 175.

52. U.S. Bureau of the Census, Migration of Nations and the Foreign Born: 1995-2000 (Washington D.C.: U.S. Government Printing Office, 2003), p. 5.

53. Kenneth R. Weiss, "Migration of Blacks from the South Turns Around," New York Times (June 11, 1989), p. 36; "Blacks in Decline in Northern Cities," New York Times (July 6, 1991), p. A-7.

54. William H. Frey, "Black Migration to the South Reaches Record Highs in 1990s," Population Today (February, 1998), p. 3.

55. Robert Walker, Mark Ellis, and Richard Barff, "Linked Migration Systems: Immigration and Internal Labor Flows in the United States," Economic Geography (July, 1992), pp. 234-248.

56. Mary Kritz and June Marie Nogle, "Nativity Concentration and Internal Migration Among the Foreign Born," Demography (August, 1994) p. 1-16.

57. Quoted in Peter Passell, "A Job-Wage Conundrum," New York Times (September 6, 1994), p. D-1; see also Richard Freeman and Lawrence F. Katz, "Industrial Wage and Employment Determination in an Open Economy," Immigration, Trade and the Labor Market, edited by John M. Abowd and Richard B. Freeman (Chicago: The University of Chicago Press, 1991), p. 241-246.

58. William H. Frey, "Immigration and Internal Migration Flight: A California Case Study," Population and Environment (March 1995), pp. 353-375; see also, William A. Frey, "Black Migration to the South ..." op. cit., pp. 1-3.

59. Alejandro Portes and Ruben G. Rumbaut, Immigrant America: A Portrait (Berkeley, University of California Press, 1990), chapter 2.

60. Philip Martin, "Network Recruitment and Labor Displacement," U.S. Immigration Policy in the 1980s, edited by David E. Simcox (Boulder: Westview Press, 1988), pp. 67-91. See also Donatella Lorch, "Ethnic Niches Creating Jobs that Fuel Immigrant Growth," New York Times (January 12, 1992), pp. A-1, A-20.

61. Elizabeth Bogen, Immigration in New York (New York: Praeger Publishers, 1987), p. 91. 
62. Ibid.

63. Jonathan Kaufman, "Help Unwanted: Immigrant Businesses Often Refuse to Hire Blacks in Inner City," Wall Street Journal (June 6, 1995), p. 1.

64. Ibid.

65. Ibid.

66. Ibid.

67. Martin, op. cit.; see also Richard Mines and Philip Martin, "Immigrant Workers and the California Citrus I ndustry," Industrial Relations (Spring, 1984), pp. 139149 .

68. David North, "Why Democratic Governments Cannot Cope with Illegal Immigrants," paper presented at the International Conference on Immigration, Rome, Italy, March 13, 1991, sponsored by the Organization for Economic Co-Operation and Development, Paris, 1991, p. 5 of xerox copy of the paper. 